\title{
Sistem Pendukung Keputusan Penerimaan Pegawai PT. Andalusia Nur Ramadhan dengan Metode Simple Additive Weighting
}

\author{
Bramantara Yudha ${ }^{1}$ \\ ${ }^{1}$ Informatika, Universitas Indraprasta, Jakarta, Indonesia \\ e-mail: ${ }^{1}$ bram.proklamatorz@gmail.com \\ Reviewed Date: December $30^{\text {th }}, 2020$ \\ Accepted Date: January $05^{\text {th }}, 2021$
}

Submitted Date: November $03^{\text {rd }}, 2020$

Revised Date: January $02^{\text {nd }}, 2021$

\begin{abstract}
The purpose of the hiring decision support system is to assist and speed up the decision-making process. There are so many methods that companies can apply in determining employee acceptance to rank prospective employees according to the results of the assessment, examples of methods that can be used are the SAW method or Simple Additive Weighting using the Java Netbeans application and the MySQL database. This research produces a system that can assist in providing decision support for hiring employees. So as to help the main director to determine and select employees who are accepted by the company PT. Andalusia Nur Ramadhan.
\end{abstract}

Keywords: SAW; Simple Additive Weighting; Decision Support Systems; Java; MySQL

\begin{abstract}
Abstrak
Tujuan sistem pendukung keputusan penerimaan pegawai adalah membantu dan mempercepat dalam proses pengambilan keputusan. Begitu banyak metode yang bisa diterapkan pihak perusahaan dalam menentukan penerimaan pegawai untuk membuat perankingan calon pegawai sesuai hasil penilaian, contoh metode yang bisa digunakan adalah Metode SAW atau Simple Additive Weighting dengan menggunakan aplikasi java netbeans dan database MySQL. Penelitian ini menghasilkan system yang dapat membantu dalam memberikan pendukung keputusan penerimaan pegawai. Sehingga membantu direktur utama untuk menentukan dan memilih pegawai yang diterima perusahaan PT. Andalusia Nur Ramadhan.
\end{abstract}

Kata Kunci: SAW; Sistem Pendukung Keputusan; Java; Simple Additive Weighting; MySQL

\section{Pendahuluan}

Penerimaan pegawai adalah tahap di mana suatu perusahaan menyeleksi calon sesuai kebutuhan untuk ditempatkan sesuai posisi. Proses seleksi penerimaan pegawai mempunyai tujuan utama untuk mendapatkan orang yang sesuai kebutuhan organisasi atau perusahaan tersebut, dimana kandidat yang dibutuhkan memiliki kemauan kerja bagus sesuai dengan etos kerja perusahaan.

Salah satu proses penerimaan pegawai adalah melalui tahap penyelesaian terhadap pegawai, dikarenakan dengan tahap penyelesaian untuk mendapatkan calon pegawai dengan kriteria yang terbaik. Adapun calon pegawai tersebut diseleksi melalui beberapa tes (Agustina, 2010). Kriteria tertentu yang ditentukan oleh setiap perusahaan berbeda. Setelah tahapan seleksi sesuai dengan kriteria perusahaan selanjutnya pengambilan keputusan calon pegawai untuk diterima sebagai pegawai (Wibowo, 2011).

Pengambilan keputusan adalah proses pemilihan dari banyak alternatif tindakan pada prosesnya melalui mekanisme tertentu. Menghubungkan proses kemudian diterjemahkan secara matematis (Nurizka, 2010). Proses pengambilan keputusan melalui tahapan proses sistematik, konsisten dengan mempertimbangkan banyak faktor.

Teknologi informasi ditujukan untuk membantu pekerjaan dengan menyediakan informasi dan melakukan berbagai tugas yang berhubungan dengan pengolahan informasi (Hanum \& Saifudin, 2019) (Hall, 2011). Pemanfaatan teknologi informasi seperti komputer untuk mendukung keputusan berbasis teknologi 
sangat tepat untuk mendapatkan pengambilan keputusan cepat (Fahmi, 2011) (Fernandes, 2015). Sistem penunjang keputusan yang menerapkan SAW (Simple Additive Weighting) dapat membantu dalam merekomendasikan (memberikan opsi terbaik) (Taufiq \& Mustofa, 2017). Sistem pendukung keputusan seleksi calon pegawai metode SAW sangat tepat karena metode ini menggunakan Teknik Fuzzy Multiple Attribute Decisison Making.

Permasalahan pengambilan keputusan memiliki berbagai kriteria terdapat pada proses penerimaan pegawai PT. Andalusia Nur Ramadhan. Permasalahan yang terjadi adalah direktur utama PT. Andalusia Nur Ramadhan kurang objektif dalam proses pemilihan pegawai sehingga untuk pemilihannya tidak sesuai dengan sasaran kinerja pegawai. Penelitian ini dibuat sebuah Sistem pendukung keputusan penerimaan pegawai PT. Andalusia Nur Ramadhan menggunakan Metode SAW.

\section{Studi Pustaka}

Pencarian meteri tentang Sistem penunjang keputusan. Pada penelitian ini menggunakan metode Metode SAW. Penjumlahan terbobot merupakan ciri dari metode ini. Penjumlahan terbobot peringkat kinerja dari alternatif semua atribut adalah dasar metode. Normalisasi matriks keputusan (X) dibutuhakan dalam bentuk skala selanjutnya peringkat dihubungkan dengan alternatif.

Pada metode ini mendefiniskan atribut kriteria kriteria biaya dan atribut keuntungan. Tahapan dalam dalam pemilihan atribut kriteria tersebut sebagai berikut:
a. Memilih Variabel alternatif (Ai).
b. Memilih kriteria acuan pengambilan keputusan dan diberikan bobot kriteria $(\mathrm{Cj})$
c. Membuat bobot tingkat kepentingan semua kriteria $\mathrm{W}=\left[\mathrm{W}_{1}, \mathrm{~W}_{2}, \ldots, \mathrm{W}_{\mathrm{J}}\right]$. peringkat kecocokan semua alternatif semua kriteria $(\mathrm{Cj})$ sudah ditentukan.
d. Menentukan matrik keputusan (X) dari tabel kriteria. Nilai X semua alternatif (Ai) semua
e. Membuat nilai peringkat kecocokan alternatif semua kriteria.
f. Menentukan tabel peringkat kecocokan semua alternatif semua kriteria.

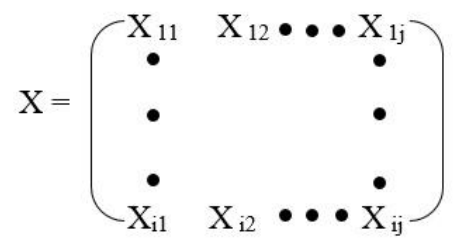

g. Menormalisasi matrik keputusan menjumlahkan nilai peringkat kinerja ternomalisasi $\left(\mathrm{r}_{\mathrm{ij}}\right)$ dari alternatif $\mathrm{Ai}$ pada kriteria $\mathrm{C}_{\mathrm{j}}$.

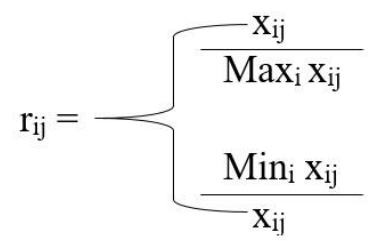

Jika $j$ : atribut keuntungan

Jika $j$ : atribut biaya

Keterangan:

$\mathrm{r}_{\mathrm{ij}} \quad$ : Peringkat kinerja ternormalisasi

$\operatorname{Max}_{\mathrm{i}}$ : Jumlah Maksimum baris dan kolom

$\operatorname{Min}_{\mathrm{i}}$ : Jumlah Minimum baris dan kolom

$\mathrm{X}_{\mathrm{ij}} \quad$ : Baris dan Kolom matriks

h. Nilai peringkat kinerja ternomalisasi (rij) terbentuk matrik ternormalisasi $(\mathrm{R})$

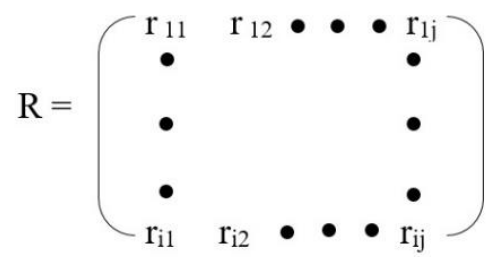

i. Nilai preferensi (Vi) merupakan jumlah perkalian elemen baris matrik ternormalisasi (R) dan bobot preferensi (W) kolom pada matrik (W).

$$
V_{i}=\sum_{j=1}^{n} W_{j} r_{i j}
$$

Keterangan:

$\mathrm{V}_{\mathrm{i}}$ : Rangking semua alternatif

$\mathrm{R}_{\mathrm{ij}}$ : Nilai peringkat kinerja normalisasi

$\mathrm{W}_{\mathrm{j}}$ : Nilai bobot semua kriteri

Nilai $\mathrm{V}_{\mathrm{i}}$ yang lebih besar menerangkan alternative Ai lebih terpilih. 


\section{Kerangka Berfikir}

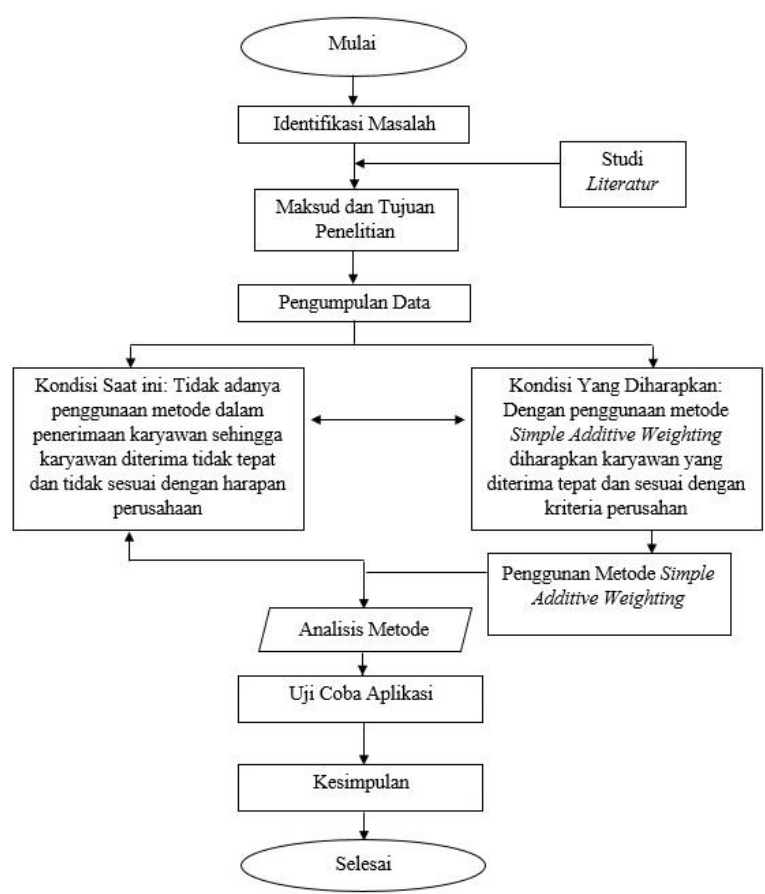

Gambar 1 Diagram Kerangka Berpikir

Pembahasan setiap bagian sebagai berikut:

a. Mulai, menerangkan sebagai langkah awal suatu tahap.

b. Identifikasi Masalah, dalam menidentifikasi masalah peneliti akan mewawancarai dan memberikan quisioner ke beberapa pihak yang ada pada proses kegiatan utama.

c. Studi pustaka, mencai bahan referensi sesuai materi yang dibahas.

d. Tujuan penelitian berupaya untuk membuat perangkat membantu melaksanakan penerimaan pegawai sesuai kriteria yang dibutuhkan.

e. Pengumpulan Data dilakukan pada dua periode waktu yaitu pada Januari 2018, yaitu:

1) Data kondisi yang menjadi permasalahan yaitu Tidak adanya penggunaan metode dalam penerimaan pegawai sehingga pegawai yang diterima tidak tepat dan tidak sesuai kriteria.

2) Data kondisi yang diharapkan yaitu dengan adanya penggunaan Metode SAW maka diharapkan proses penerimaan pegawai yang tepat sesuai kriteria.

f. Tahapan-tahpan dalam mengolah data dengan menggunakan Metode SAW :

1) Mengindentifikasi kritteria-kriteria dalam pemilihan pegawai sesuai dengan prosedur perusahaan.
2) Mengetahui cara penyelesaian masalah menggunkan metode SAW.

3) Membedakan pembuatan aplikasi sistem pendukung keputusan penerimaan pegawai untuk mendapatkan pegawai yang tepat sesuai kriteria.

4) Melakukan sosialisasi penggunaan metode sistem pendukung keputusan seleksi pegawai terhadap pihak yang terkait di perusahaan.

g. Analisis Metode, analisis ini berisi sudah tepatkah penggunaan metode SAW untuk seleksi penerimaan pegawai yang diterapkan dalam melakukan penerimaan pegawai yang akan dirapkan ke dalam perusahaan sehingga mendapatkan pegawai yang tepat.

h. Untuk menjamin kualitas sistem/aplikasi yang dikembangkan harus melalui tahap uji coba (Pratala, Asyer, Prayudi, \& Saifudin, 2020). Uji coba aplikasi, sebelum aplikasi diterapkan ke perusahaan sebaiknya terlebih dahulu sistem dilakukan uji kelayakan, agar jika kesalahan-kesalahan fungsi dapat diatasi. Pengujian sistem bertujuan untuk memastikan bahwa semua proses sudah berfungsi sesuai dengan kebutuhan yang ditetapkan (Muslimin, et al., 2020).

i. Simpulan, setelah melakukan uji coba aplikasi, selanjutnya dilakukan penarikan kesimpulan. Berdasarkan hasil analisis penggunaan metode ini, digunakan untuk memberikan saran-saran terhadap pihak PT. Andalusia Nur Ramadhan.

j. Selesai, tahap ini menerangkan bahawa suatu pekerjaan telah selesai.

\section{Metode Penelitian}

Metode penelitian adalah kegiatan menghasilkan data berguna untuk tujuan penelitian. Cara ilmiah tersebut mempunyai karekteristik yang rasional, empiris, dan sistematis (Sugiyono, 2008). Penelitian dilaksanakan untuk membuat sistem pendukung keputusan penerimaan pegawai berbasis komputer pada PT. Andalusia Nur Ramadhan didilakukan peneliti untuk mendapatkan data untuk mendukung penelitian:

a. Observasi untuk mempelajari berhubungan dengan sistem penerimaan pegawai yang terdapat pada PT. Andalusia Nur Ramadhan beserta hubungan dengan antarbagian didalam perusahaan.

b. Interview bertujuan menerima data pendapat responden yang diwawancarai tentang kondisi sistem. Dalam penelitian ini, peneliti bertanya langsung dengan direktur utama dan pegawai 
mengenai sistem penerimaan pegawai pada PT. Andalusia Nur Ramadhan.

c. Kuisioner dilakukan untuk pengumpulan data dengan cara memberikan beberapa pertanyaan,kuisioner ini akan diberikan kepada pegawai yang sudah bekerja di PT. Andalusia Nur Ramadhan termasuk direktur utama.

\section{Perancangan dan Implementasi}

Pada pengembangan aplikasi sistem penunjang keputusan digunakan database MySQL untuk menyimpan datanya. Database yang digunakan harus hemat memori dan mudah diakses (Connolly, 2010). Sedangkan aplikasinya menggunakan pemrograman PHP karena umum digunakan untuk aplikasi web (Nugroho, 2013).

Penggunaan perangkat untuk mengambaran system menggunakan diagram flowchart sangat membantu menjelaskan alur sistem (Anhar, 2010). Flowchart pada Sistem Pendukung Keputusan Penerimaan Pegawai PT. Andalusia Nur Ramadhan adalah sebagai berikut:

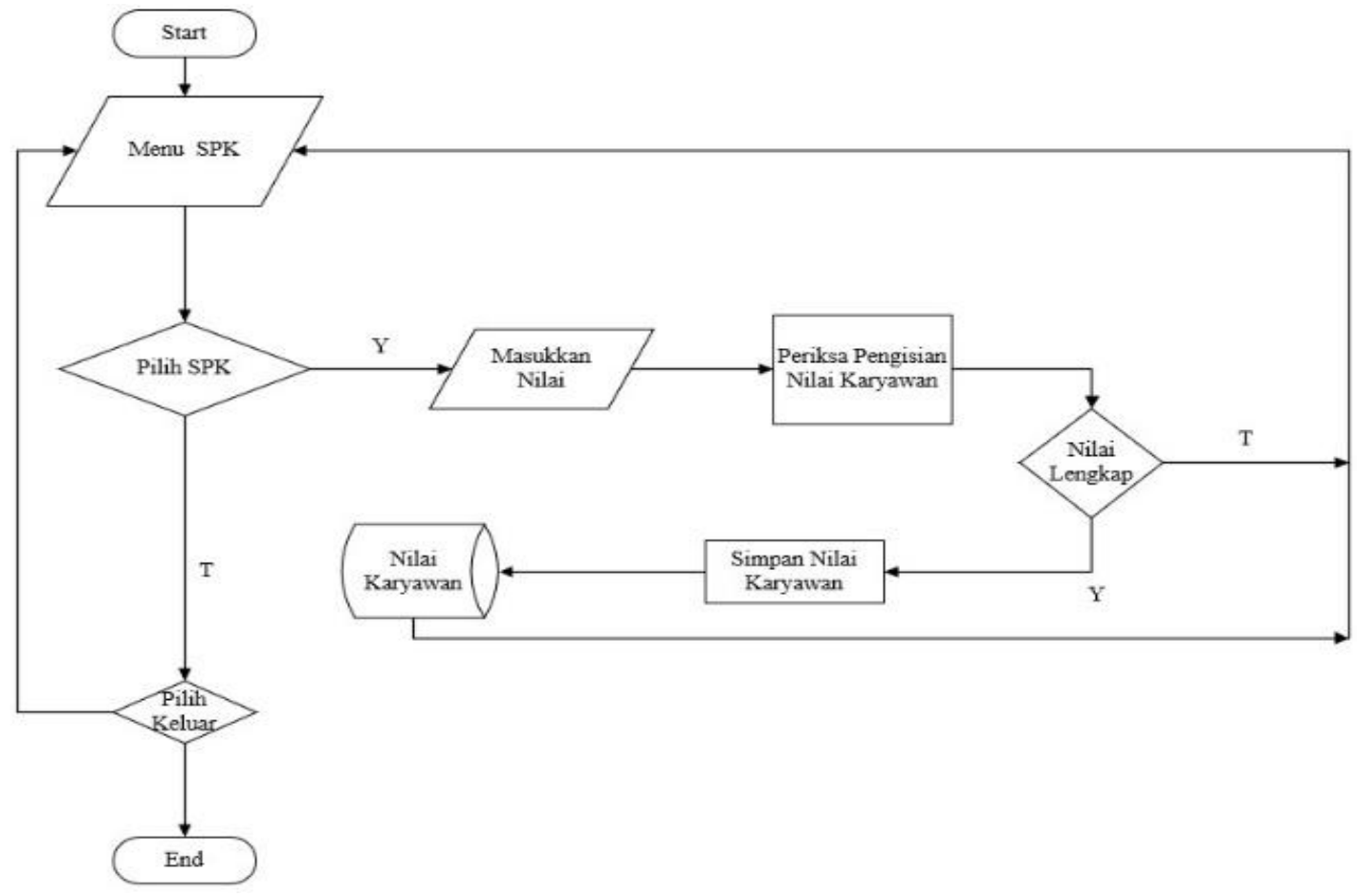

Gambar 2 Flowchart SPK

Langkah awal perhitungan pegawai menggunakan metode SAW pertama kali yaitu memberikan bobot nilai semua kriteria. Kriteria tersebut sesuai pada tabel 1:

Tabel 1 Kriteria

\begin{tabular}{|c|l|}
\hline Kriteria & Keterangan \\
\hline C1 & Psikotes \\
\hline C2 & Wawancara \\
\hline C3 & Tes \\
\hline C4 & Keahlian \\
\hline C5 & Kecakapan \\
\hline C6 & Kedisiplinan \\
\hline C7 & Prestasi \\
\hline
\end{tabular}

Setiap kriteria selanjutnya ditentukan masing-masing bobotnya.
Tabel 2 Bobot

\begin{tabular}{|c|l|}
\hline Bobot & \multicolumn{1}{|c|}{ Keterangan } \\
\hline 0.2 & Sangat Rendah \\
\hline 0.4 & Rendah \\
\hline 0.6 & Sedang \\
\hline 0.8 & Tinggi \\
\hline 1 & Sangat Tinggi \\
\hline
\end{tabular}

Berdasarkan tahapan seleksi penerimaan calon pegawai baru menggunakan metode $S A W$.

1. Menentukan nilai setiap alternatif $\left(\mathrm{A}_{\mathrm{i}}\right)$ pada setiap kriteria $\left(\mathrm{C}_{\mathrm{j}}\right)$. 
Tabel 3 Psikotes

\begin{tabular}{|c|c|l|}
\hline Karakter & Nilai & \multicolumn{1}{c|}{ Keterangan } \\
\hline 1 & 1 & Sangat Baik \\
\hline 2 & 0,8 & Baik \\
\hline 3 & 0,6 & Cukup \\
\hline 4 & 0,4 & Buruk \\
\hline 5 & 0,2 & Sangat Buruk \\
\hline
\end{tabular}

Tabel 4 Keahlian

\begin{tabular}{|c|c|l|}
\hline Karakter & Nilai & \multicolumn{1}{|c|}{ Keterangan } \\
\hline 1 & 1 & Sangat Baik \\
\hline 2 & 0,8 & Baik \\
\hline 3 & 0,6 & Cukup \\
\hline 4 & 0,4 & Buruk \\
\hline 5 & 0,2 & Sangat Buruk \\
\hline
\end{tabular}

Tabel 5 Wawancara

\begin{tabular}{|c|c|l|}
\hline Karakter & Nilai & \multicolumn{1}{|c|}{ Keterangan } \\
\hline 1 & 1 & Sangat Baik \\
\hline 2 & 0,8 & Baik \\
\hline 3 & 0,6 & Cukup \\
\hline 4 & 0,4 & Buruk \\
\hline 5 & 0,2 & Sangat Buruk \\
\hline
\end{tabular}

Tabel 6 Tes

\begin{tabular}{|c|c|l|}
\hline Karakter & Nilai & \multicolumn{1}{|c|}{ Keterangan } \\
\hline 1 & 1 & Sangat Baik \\
\hline 2 & 0,8 & Baik \\
\hline 3 & 0,6 & Cukup \\
\hline 4 & 0,4 & Buruk \\
\hline 5 & 0,2 & Sangat Buruk \\
\hline
\end{tabular}

Tabel 7 Kedisiplinan

\begin{tabular}{|c|c|l|}
\hline Karakter & Nilai & Keterangan \\
\hline 1 & 1 & Sangat Baik \\
\hline 2 & 0,8 & Baik \\
\hline 3 & 0,6 & Cukup \\
\hline 4 & 0,4 & Buruk \\
\hline 5 & 0,2 & Sangat Buruk \\
\hline
\end{tabular}

Tabel 8 Kecakapan

\begin{tabular}{|c|c|l|}
\hline Karakter & Nilai(Bobot) & \multicolumn{1}{c|}{ Keterangan } \\
\hline 1 & 1 & Sangat Baik \\
\hline 2 & 0,8 & Baik \\
\hline 3 & 0,6 & Cukup \\
\hline 4 & 0,4 & Buruk \\
\hline 5 & 0,2 & Sangat Buruk \\
\hline
\end{tabular}

Tabel 9 Prestasi

\begin{tabular}{|l|l|l|} 
Karakter & Nilai & Keterangan \\
\hline
\end{tabular}

\begin{tabular}{|c|c|l|}
\hline 1 & 1 & Sangat Baik \\
\hline 2 & 0,8 & Baik \\
\hline 3 & 0,6 & Cukup \\
\hline 4 & 0,4 & Buruk \\
\hline 5 & 0,2 & Sangat Buruk \\
\hline
\end{tabular}

2. Proses perhitungan ini menggunakan sample data pelamar sebanyak 2 data. Data calon pegawai yang melamar pekerjaan sebagai pemasaran pertama dengan nama Jono berusia 21 tahun dan calon kedua bernama Ucup berusia 28 tahun. Proses test dan wawancara sudah dilakukan oleh pelamar kerja pada bagian Sumber Daya Manusia dengan hasil yang sudah tercatat dalam table-tabel. Tabel tersebut mencatat peringkat kecocokan dari setiap alternatif $\left(A_{i}\right)$ semua kriteria $\left(C_{j}\right)$.

Tabel 10 Data Penilaian

\begin{tabular}{|l|c|c|c|c|c|c|c|}
\hline \multirow{2}{*}{ Alternatif } & \multicolumn{7}{|c|}{ Kriteria } \\
\cline { 2 - 8 } & C1 & C2 & C3 & C4 & C5 & C6 & C7 \\
\hline Joko & 0.4 & 0.6 & 0.4 & 0.4 & 0.6 & 0.4 & 0.4 \\
\hline Ucup & 0.6 & 0.6 & 0.2 & 0.4 & 0.4 & 0.8 & 0.4 \\
\hline
\end{tabular}

Tabel 11 Peringkat Kecocokan

\begin{tabular}{|l|l|l|l|l|l|l|l|}
\hline \multirow{2}{*}{ Alternatif } & \multicolumn{7}{|c|}{ Kriteria } \\
\cline { 2 - 8 } & C1 & C2 & C3 & C4 & C5 & C6 & C7 \\
\hline Joko & 2 & 3 & 2 & 2 & 3 & 2 & 2 \\
\hline Ucup & 3 & 3 & 1 & 2 & 2 & 4 & 2 \\
\hline
\end{tabular}

3. Berdasarkan Gambar Tabel 11 Peringkat Kecocokan membentuk matriks keputusan X berikut ini :

$$
X=\left[\begin{array}{l}
0.4,0.6,0.4,0.4,0.6,0.4,0.4 \\
0.6,0.6,0.2,0.4,0.4,0.8,0.4
\end{array}\right]
$$

4. Nilai bobot (W) menentukan bobot pada posisi pemasaran sesuai tabel 12 :

Tabel 12 Bobot Posisi Marketing

\begin{tabular}{|l|l|l|}
\hline Kriteria & Bobot & Keterangan \\
\hline C1 & 0.6 & Sedang \\
\hline C2 & 1 & Sangat Tinggi \\
\hline C3 & 0.8 & Tinggi \\
\hline C4 & 0.6 & Sedang \\
\hline C5 & 1 & Sangat Tinggi \\
\hline C6 & 0.4 & Rendah \\
\hline C7 & 0.8 & Tinggi \\
\hline
\end{tabular}


5. Dari Tabel 12 Bobot Untuk Posisi pemasaran diperoleh nilai bobot (W) sebagai berikut : W $=\{0.6,1,0.8,0.6,1,0.4,0.8\}$

6. Menormalisasi matriks $\mathrm{X}$ menjadi matriks $\mathrm{R}$ berdasarkan persamaan, Sistem Pendukung Keputusan.

$$
\mathrm{r}_{\mathrm{ij}}=\underbrace{}_{\frac{\mathrm{x}_{\mathrm{ij}}}{\operatorname{Max}_{\mathrm{i}} \mathrm{x}_{\mathrm{ij}}}}{ }^{\frac{\operatorname{Min}_{\mathrm{i}} \mathrm{x}_{\mathrm{ij}}}{\mathrm{x}_{\mathrm{ij}}}}
$$

Keterangan:

[1] Jika $j$ : atribut keuntungan (benefit)

[2] Jika $j$ : atribut biaya (cost)

$\mathrm{r}_{\mathrm{ij}} \quad=$ Nilai peringkat kinerja ternormalisasi.

$\mathrm{x}_{\mathrm{ij}}=$ Nilai atribut alternatif setiap kriteria.

$\operatorname{Min}_{\mathrm{i}}=$ Nilai terkecil.

$\operatorname{Max}_{\mathrm{i}}=$ Nilai terbesar.

benefit $=$ Nilai terbaik adalah nilai terbesar. $\cos t=$ Nilai terbaik adalah nilai terkecil .

a. Kriteria Psikotes merupakan atribut keuntungan.

$$
\begin{aligned}
& r_{11}=0.4 \\
& \operatorname{Max}\{0.4 ; 0.6\} \quad 0.6- \\
& \mathrm{r}_{21}=\frac{0.6=}{\operatorname{Max}\{0.4 ; 0.6\}} \quad \frac{0.6}{0.6}=1
\end{aligned}
$$

b. Kriteria Wawancara adalah atribut keuntungan

$$
\begin{aligned}
& \mathrm{r}_{12}=\frac{0.6}{\operatorname{Max}\{0.6 ; 0.6\}}=0.6=1 \\
& \mathrm{r}_{22}=\quad 0.6=0.6=1 \\
& \operatorname{Max}\{0.6 ; 0.6\} 0.6
\end{aligned}
$$

c. Kriteria Tes adalah atribut keuntungan

$$
\begin{aligned}
& \mathrm{r}_{13}=\frac{0.4}{\operatorname{Max}\{0.4 ; 0.2\}}=0.4 \frac{1}{0.4} \\
& \mathrm{r}_{23}=\frac{0.2}{\operatorname{Max}\{0.4 ; 0.2\}}=0.2=0.5
\end{aligned}
$$

d. Kriteria Keahlian adalah atribut keuntungan

$$
\begin{array}{cc}
\mathrm{r}_{14}=\frac{0.4}{\overline{\operatorname{Max}\{0.4 ; 0.4\}}}=0.4=1 \\
\mathrm{r}_{24}=\frac{0.4}{\operatorname{Max}\{0.4 ; 0.4\}}=0 . \overline{4} & 0 . \overline{4}=1
\end{array}
$$

e. Kriteria Kecakapan adalah atribut keuntungan

$$
\begin{aligned}
& \mathrm{r}_{15}=\begin{array}{cc}
0.6 & =0.6=1 \\
\operatorname{Max}\{0.6 ; 0.4\} & 0.6
\end{array} \\
& \mathrm{r}_{25}=\frac{0.4}{\operatorname{Max}\{0.6 ; 0.4\}}=0.4=0.67
\end{aligned}
$$

f. Kriteria Kedisiplinan adalah atribut biaya

$$
\begin{aligned}
& r_{16}=\frac{\operatorname{Min}\{0.4,0.8\}}{0.4}=\frac{0.4}{0.4}=1 \\
& r_{26}=\frac{\operatorname{Min}\{0.4,0.8\}}{0.8}=\frac{0.4}{0.8}=0.5
\end{aligned}
$$

g. Kriteria Prestasi adalah atribut keuntungan

$$
\begin{aligned}
& \mathrm{r}_{17}=\frac{0.4}{\operatorname{Max}\{0.4 ; 0.4\}}=\frac{0.4}{0.4}=1 \\
& \mathrm{r}_{27}=\frac{0.4}{\operatorname{Max}\{0.4 ; 0.4\}}=\frac{0.4}{0.4}=1
\end{aligned}
$$

7. Hasil normalisasi matriks $\mathrm{X}$ adalah matriks $\mathrm{R}$ berikut ini:

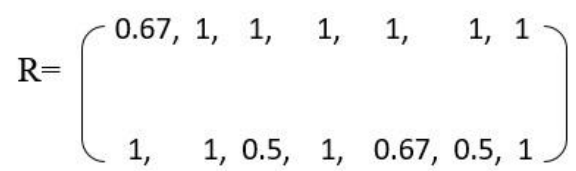

8. Proses perangkingan menggunakan persamaan.

$$
V_{i}=\sum_{j=1}^{n} W_{j} r_{i j}
$$

Keterangan :

$\mathrm{V}_{\mathrm{i}}=$ Peringkat semua alternatif

$\mathrm{r}_{\mathrm{ij}}=$ Nilai peringkat kinerja normalisasi

$\mathrm{W}_{\mathrm{j}}=$ Nilai bobot semua kriteria

beikut adalah hasil yang diperoleh :

a. Joko $=(0.6) \mathrm{x}(0.67)+(1) \mathrm{x}(1)+(0.8) \mathrm{x}(1)+$ $(0.6) \times(1)+(1) \times(1)+$

$(0.4) \mathrm{x}(1)+(0.8) \mathrm{x}(1)=0.40+1+0.8+$ $0.6+1+0.4+0.8=5$

b. $\quad$ Ucup $=(0.6) \times(1)+(1) \times(1)+(0.8) \times(0.5)+$ $(0.6) \times(1)+(1) \times(0.67)+(0.4) \times(0.5)+$ $(0.8) \times(1)=0.6+1+0.4+0.6+0.67+0.2$ $+0.8=4.27$

Joko memiliki nilai terbesar sehingga alternatif Calon Pegawai Baru yaitu Joko. Joko merupakan alternatif menjadi alternatif terbaik calon pegawai untuk PT. Andalusia Nur Ramadhan. Penjelasan terdapat pada Tabel 13. 
Tabel 13 Penilaian Calon Pegawai Baru

\begin{tabular}{|l|l|l|l|l|l|l|l|}
\hline \multirow{2}{*}{ Alternatif } & \multicolumn{7}{|c|}{ Kriteria } \\
\cline { 2 - 8 } & PS & WW & TS & AH & CP & DP & PS \\
\hline Joko & 0.40 & 1 & 0.8 & 0.6 & 1 & 0.4 & 0.8 \\
\hline Ucup & 0.6 & 1 & 0.4 & 0.6 & 0.67 & 0.2 & 0.8 \\
\hline
\end{tabular}

\section{Uji Coba Program}

Berikut ini adalah hasil perancangan berupa program sistem penunjang keputusan pemilihan pegawai seperti pada tampilan berikut:

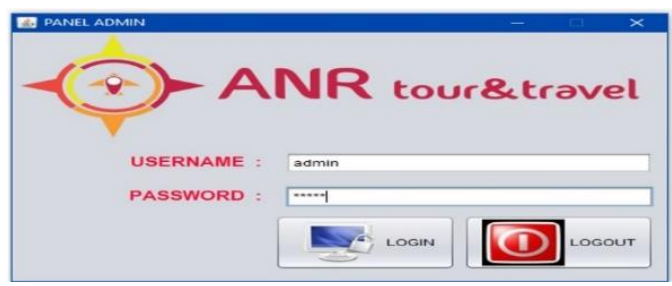

Gambar 3. Login User

Pada tampilan layar Menu Login ini merupakan menu masuk ke dalam aplikasi program dengan memasukan username dan password yang sudah disimpan ke dalam database. Pada tampilan form login ini terdapat pilihan tombol login dan tombol logout, admin adalah username dan password masuk sistem. Jika akun yang dimasukkan sesuai maka berlanjut ke Menu Utama.

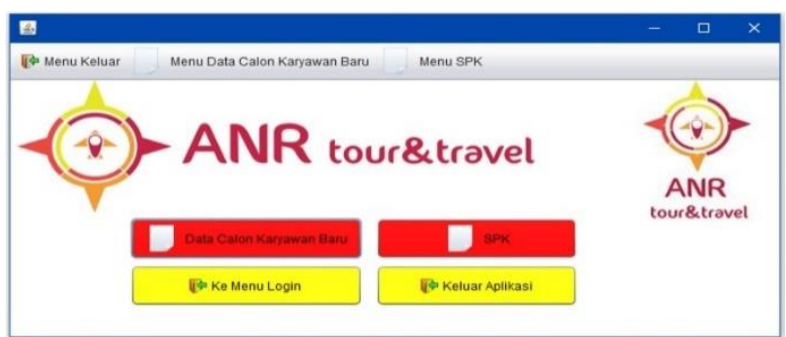

Gambar 4. Menu Utama

Tampilan menu utama aplikasi ini berisikan Menu Keluar, Menu Data Calon Pegawai Baru, Menu SPK, Tombol Button Calon Data Pegawai Baru, Tombol Button SPK, Tombol Button Ke Menu Login, Tombol Button Keluar Aplikasi. Seluruh Menu berjalan dengan baik.

Tampilan menu ini berisikan sub menu Data Calon Pegawai Baru sedangkan Tombol Button ini berisikan Tombol Button Data Calon Pegawai Baru yang di dalamnya terdapat kolom: Id Calon Pegawai, Nama, Tempat dan Tanggal Lahir, Jenis Kelamin, No Telepon, Alamat dan Pendidikan. Dimana terdapat juga 6 buah Tombol Button:

a. Simpan, berfungsi sebagai media penyimpanan dan menambahkan data calon pegawai baru yang diinputkan ke dalam database jika seluruhnya sudah terisi dengan benar dan tepat sesuai data calon pegawai baru.

b. Reset, berfungsi proses menghilangkan datadata pada kolom-kolom sehingga kolomkolom terlihat seperti baru.

c. Edit, berfungsi sebagai media perubahan data calon pegawai baru bila ada data yang salah dalam memaskan ke basisdata.

d. Hapus, berfungsi menghapus data calon pegawai baru yang sudah di-input ke dalam database jika data calon pegawai tersebut dinyatakan salah atau data sudah tidak berguna.

e. Print, berfungsi untuk mencetak data calon pegawai baru yang sudah tersimpan di dalam database.

f. Refresh, Berfungsi untuk memperbarui form menu data calon pegawai baru dan tombol button data calon pegawai baru.

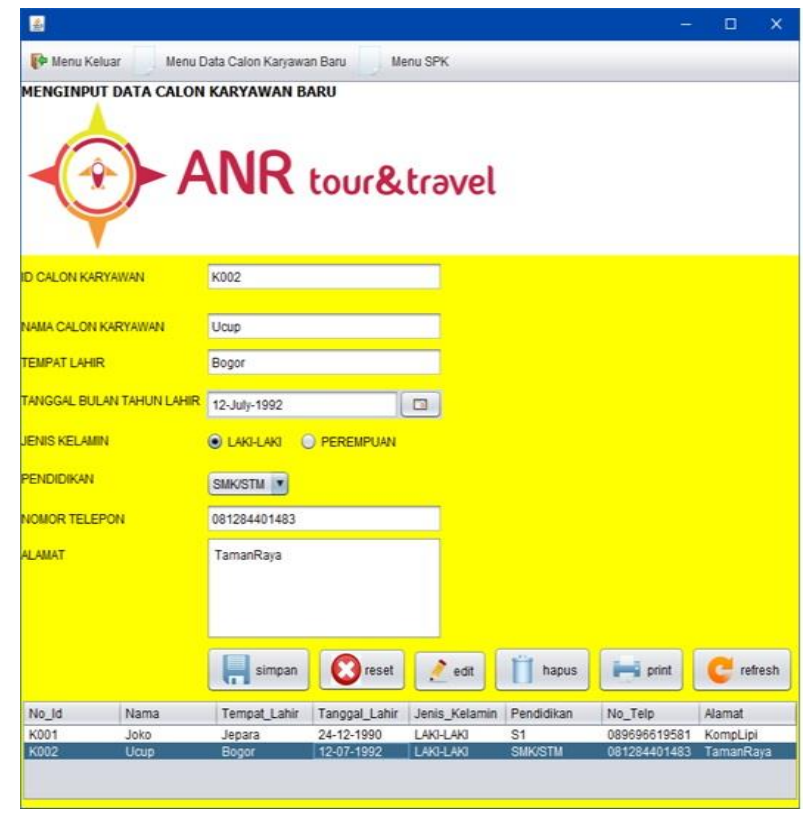

Gambar 5 Menu Data Calon Pegawai Baru 


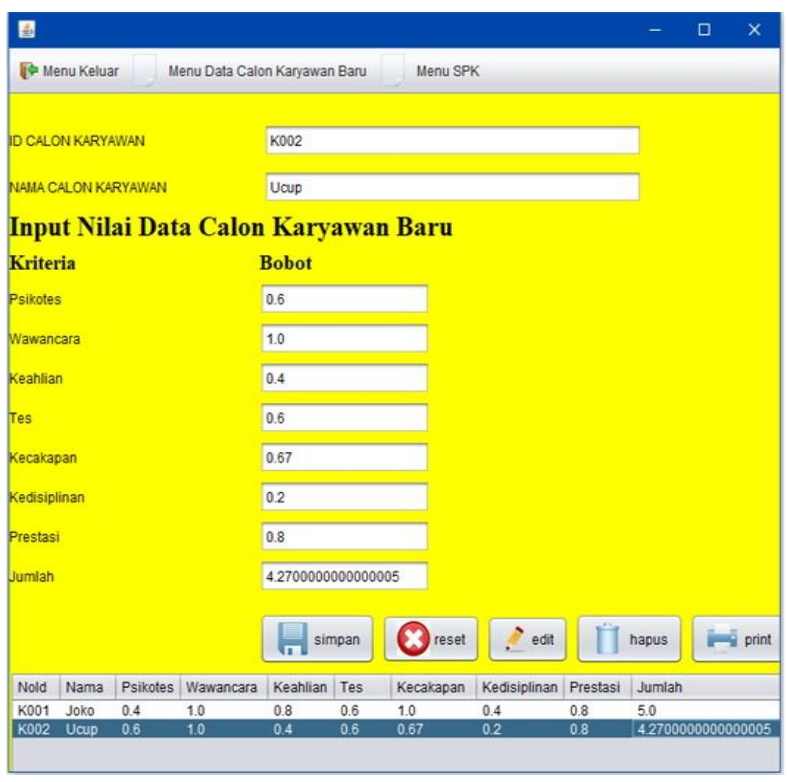

Gambar 6 Menu SPK

\section{LAPORAN DATA CALON KARYAWAN BARU}
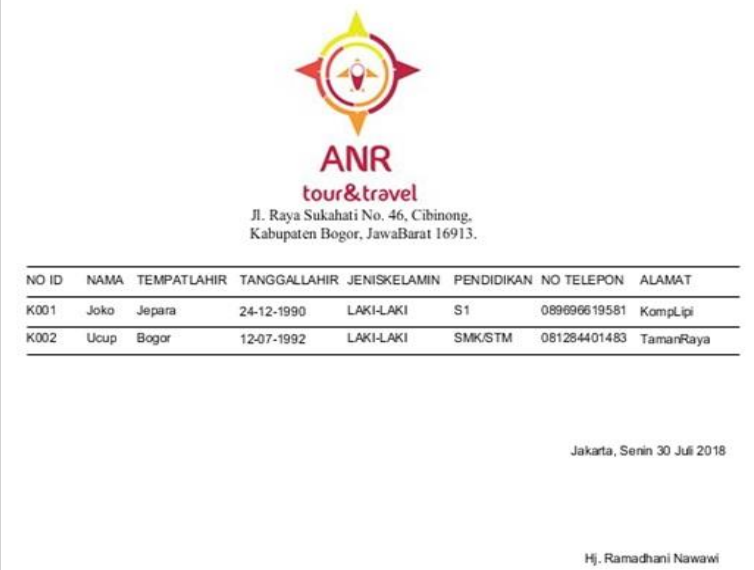

Gambar 7 Laporan Calon Pegawai Baru

\section{LAPORAN NILAI DATA CALON KARYAWAN BARU}

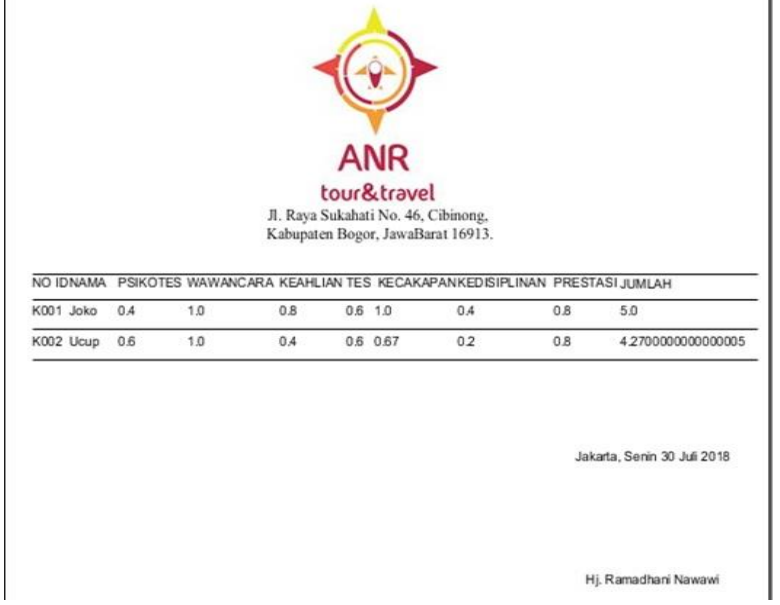

Gambar 8 Laporan Nilai Calon Pegawai Baru
Pada tampilan menu ini ditujukan untuk keluar dari aplikasi jika tidak lagi menggunkan aplikasi. Seluruh sub menu dari menu ini (Ke Menu Login dan Keluar Aplikasi) sudah berjalan dengan baik

\section{Simpulan}

Berdasarkan hasil penelitian tentang sistem pendukung keputusan tentang penerimaan pegawai dengan metode $S A W$ kesimpulan yang diperoleh adalah:

1. Sistem yang dirancang menghasilkan keputusan optimal untuk menentukan calon pegawai yang berhak diterima. Sistem menggunakan metode $S A W$ menggunakan 7 kriteria yaitu Psikotes, Wawancara, Kecakapan, Keahlian, Tes, Kedisiplinan, Prestasi. Kriteria tersebut memilki nilai Sangat Buruk, Buruk, Cukup, Baik, Sangat Baik.

2. Sistem yang dirancanga membantu untuk perusahaan dalam pengambilan keputusan penerimaan pegawai sesuai kriteria yang dibutuhkan.

\section{Saran}

Sebuah sistem yang dirancang tidak pernah sempurna karena sistem terus disesuaikan dengan kebutuhan pemakai. Terdapat beberapa saran untuk perkembangan sistem lebih lanjut:

1. Penelitian ini disarankan menggunakan metode lain sebagai perbandingan metode.

2. Metode dapat digunakan untuk kasus yang lain diman masih berkorelasi dengan penelitian ini.

3. Bentuk perancangan dapat dikembangkan untuk menyempurnakan metode dalam sistem ini.

\section{Referensi}

Agustina, F. W. (2010). Pengaruh Sikap, Norma Subjektif, Dan Kewajiban Moral Terhadap Tindakan Wajib Pajak Pribadi di KPP Serpong. Jakarta: Universitas Pembangunan Nasional .

Anhar. (2010). Panduan Menguasai PHP dan MYSQL Secara Otodidak. Jakarta: Mediakita.

Connolly, T. a. (2010). Database Systems A Practical Approach to Design, Implementation, and Management Fifth Edition. Boston: Pearson Education.

Fahmi, I. (2011). Sistem Pendukung Keputusan Penjurusan Sma Menggunakan Metode SAW. STMIK Atma Luhur Pangkalpinang: Semantik 2012. 
Fernandes, I. (2015). Sistem Pendukung . STMIK GI MDP Palembang.

Hall, J. A. (2011). Accounting Information System. Jakarta: Salemba Empat.

Hanum, W. S., \& Saifudin, A. (2019). Rancang Bangun Aplikasi Panduan Pariwisata di Kabupaten Banyuwangi Mobile Berbasis Android. Jurnal Teknologi Sistem Informasi dan Aplikasi, 2(2), 59-65. doi:10.32493/jtsi.v2i2.2798

Muslimin, D. B., Kusmanto, D., Amilia, K. F., Ariffin, M. S., Mardiana, S., \& Yulianti, Y. (2020). Pengujian Black Box pada Aplikasi Sistem Informasi Akademik Menggunakan Teknik Equivalence Partitioning. Jurnal Informatika Universitas Pamulang, 5(1), 19-25. doi:10.32493/informatika.v5i1.3778

Nugroho, B. (2013). Dasar Pemograman Web PHP MySQL dengan Dreamweaver. Yogyakarta: Gava Media.

Nurizka, L. (2010). Judul Skripsi Perancangan Aplikasi Sistem Pendukung Keputusan . Universitas Indraprasta PGRI.

Pratala, C. T., Asyer, E. M., Prayudi, I., \& Saifudin, A. (2020). Pengujian White Box pada Aplikasi Cash Flow Berbasis Android Menggunakan Teknik Basis Path. Jurnal Informatika Universitas Pamulang, 5(2), 111-119. doi:informatika.v5i2.4713

Sugiyono. (2008). Metode Penelitian Bisnis. Bandung: Alfabeta.

Susanto, A. (2013). Sistem Informasi Akuntansi. Bandung: Lingga Jaya.

Taufiq, R., \& Mustofa, I. S. (2017). Perancangan Sistem Pendukung Keputusan Kejurusan Menggunakan Metode Simple Additive Weighting (SAW) Di SMA Negri 15 Tangerang. Jurnal TI Atma Luhur, 4(1), 103114.

Wibowo, B. A. (2011). Perancangan dan Implementasi Sistem Pendukung Keputusan untuk Jalan Menggunakan Metode ID3 (Studi Kasus BAPPEDA Kota Salatiga). Jawa Tengah: Universitas Kristen Satya Wacana. 